Article

\title{
New Heat Transfer Fluids (HTFs) for Solar Thermal Applications
}

\author{
Thies Thiemann, ${ }^{1}$, Yosef Al Jasem, ${ }^{2}$ Bassam Al Hindawi, ${ }^{1}$ Hifsa Butt, ${ }^{2}$ Mohamed Barkhad, ${ }^{2}$ \\ Mona Al Khazali, ${ }^{3}$ Mariam Al-Azani ${ }^{1}$
}

${ }^{1}$ Department of Chemistry, ${ }^{2}$ Department of Chemical Engineering, ${ }^{3}$ Department of Petroleum Engineering, United Arab Emirates University, Al Ain, Abu Dhabi, United Arab Emirates.

E-mail: thies@uaeu.ac.ae

* Tel.: +971-56-692-5943; Fax: +971-3-767-1291

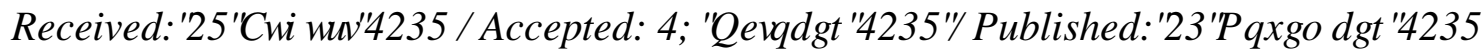

\begin{abstract}
Heat transfer fluids (HTFs) are used widely in many industrial processes. They collect and transport thermal energy in process heating, metal working, machine cooling with applications in the aerospace, automotive, and marine industries. Also, these fluids comprise one of the key technological components in electricity generation from concentrating solar power systems (CSPs), where they can store thermal energy as a sensible heat reservoir for later delivery to the power conversion system in absence of solar radiation. In the current work, a new one pot strategy towards biarylated ethers as novel Heat Transfer Fluids, while using minimal amount of reaction solvent, has been developed.
\end{abstract}

Keywords: Heat Transfer Fluids; biarylated ethers; Solar Thermal Energy Generation.

\section{Introduction}

The selection of heat transfer fluid and the system design in industrial processes is the main factor for achieving maximum heat transfer with minimum input energy and cost [1]. In general, heat transfer fluids (HTFs) and thermal oils for high temperature applications vary in chemical composition. Many of them are synthetic, and they include ester and diester, polyglycol and water-glycol based fluids, as 
well as silicone based greases and oils. They can be formulated from both organic and inorganic compounds. Often, non-synthetic HTFs consist of petroleum or mineral oils, some of which have water included. For high operating temperatures in heat storage and transport, liquid sodium, or molten nitrate salts (sodium nitrate-potassium nitrate) can be used. In the past, most organic heat transfer fluids based on aromatic or aliphatic petrochemicals were used in the temperature range of $0-350{ }^{\circ} \mathrm{C}$. However, at higher temperatures, they tend to decompose or oxidize [2]. Nevertheless, synthetic organic HTFs have gained more interest with time, as, though they are more expensive, they provide better thermal properties than the non-synthetic products. HTFs and thermal oils vary in terms of kinematic viscosity, operating temperature, pour point, boiling point, and flash point. Some of the main characteristics of an HTF as an energy storage system are its capacity for storing thermal energy per unit volume, its toxicity and the temperature range over which it operates[3].

In general, the following characteristics are important for the evaluation of an HTF for CSPs: (high heat capacity, high thermal conductivity, high flash point, large operating range as where temperature is concerned (low melting point and high boiling point), low viscosity and density of the fluid and high vapor pressure) [4].

HTFs can present potential pollution problems [5]. Many of the HTFs used have relatively poor heat transfer characteristics. Additionally, at ambient temperature, many of them are more viscous than water, are less dense than water, and have lower specific heat capacity and thermal conductivity than water. These characteristics force the operators to use higher flow rates, resulting in greater pumping power necessary to obtain the equivalent quantity of energy transported when compared to a system using water.

For a new solar thermoelectric generator [6], the authors have been searching for suitable organic HTFs. In the following, the authors discuss the synthesis of a number of new aryl ethers as potential HTFs. 10 years after J. Metzger's seminal article and 20 years after the Rio conference [7], it continues to be crucial to use chemical resources effectively. While it is quite evident that the purification of reaction products consumes more solvents than the reactions themselves, in addition to solid phase material, such as silica gel, it is also true that these can be recycled more easily than the solvents used in the reactions themselves. From this viewpoint, the authors have explored the possibility of solvent minimization for their reactions. Also, the authors have explored one-pot syntheses, combining etherification and Suzuki-Miyaura cross-coupling reactions, partly under solventless conditions.

\section{Results and Discussion}

\section{Synthesis}




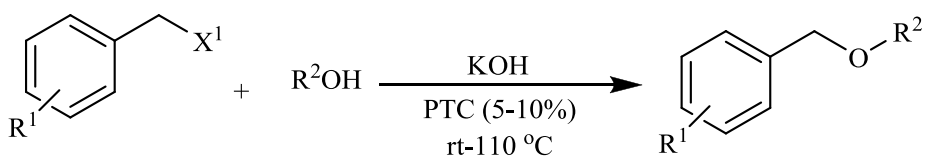

1a: $\mathrm{R}^{1}=4-\mathrm{Br}, \mathrm{X}^{1}=\mathrm{Br}$

lb: $\mathrm{R}^{1}=4-\mathrm{H}, \mathrm{X}^{1}=\mathrm{Cl}$

1c: $\mathrm{R}^{1}=3-\mathrm{Br}, \mathrm{X}^{1}=\mathrm{Br}$ 2a: $\mathrm{R}^{1}=4-\mathrm{Br}, \mathrm{R}^{2}=$ Prop

2b: $\mathrm{R}^{1}=4-\mathrm{Br}, \mathrm{R}^{2}=\mathrm{But}$

2c: $\mathrm{R}^{1}=4-\mathrm{Br}, \mathrm{R}^{2}=$ Pent

2d: $\mathrm{R}^{1}=4-\mathrm{Br}, \mathrm{R}^{2}=\mathrm{Hex}$

2e: $\mathrm{R}^{1}=4-\mathrm{Br}, \mathrm{R}^{2}=\mathrm{Hept}$

2f: $\mathrm{R}^{1}=4-\mathrm{Br}, \mathrm{R}^{2}=$ Phenyl

2g: $\mathrm{R}^{1}=4-\mathrm{Br}, \mathrm{R}^{2}=$ Benzyl

2h: $\mathrm{R}^{1}=4-\mathrm{H}, \mathrm{R}^{2}=$ Phenyl

2i: $\mathrm{R}^{1}=4-\mathrm{Br}, \mathrm{R}^{2}=1$-(Phenyl) ethyl

$2 \mathrm{j}: \mathrm{R}^{1}=3-\mathrm{Br}, \mathrm{R}^{2}=1-($ Phenyl) ethyl

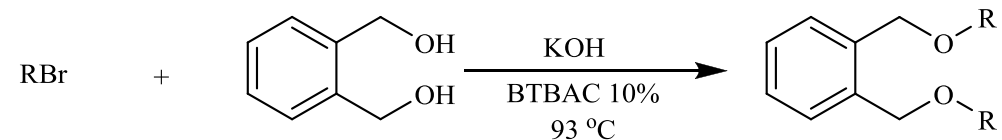

1a: $R=4$-bromobenzyl

$2 \mathrm{k}(92 \%)$

\section{Scheme 1}

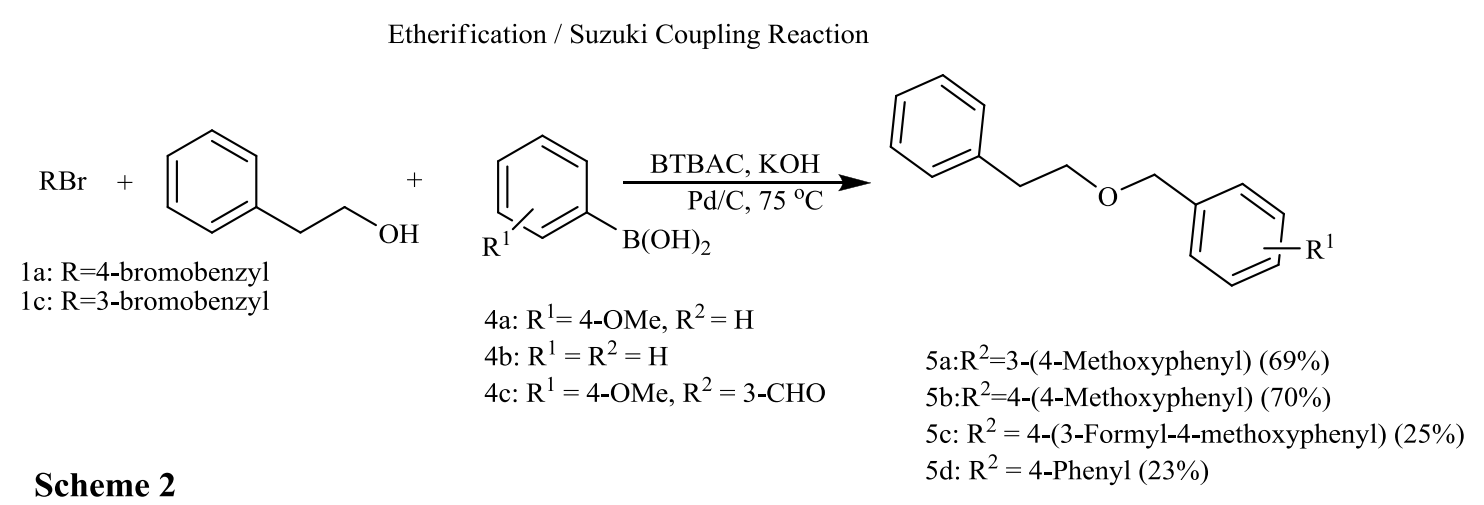

Benzyl ethers (2) were prepared under phase transfer catalysis (PTC) under solventless conditions (Scheme 1). Here, the authors fell back upon a strategy by Rao and Senthilkumar [8] for the etherification of alkyl bromides and alkanols, which uses ground potassium hydroxide as base and tetralkylammonium halides as phase transfer catalysts. However, the authors could show that not only liquid alkyl bromides and alkanols can undergo the reaction under the solventless conditions, but that the reactions go equally well, if one or both of the reaction partners are solids. The reaction mixtures could be heated up to $75{ }^{\circ} \mathrm{C}$ without any noticeable decomposition of the ammonium salt phase transfer catalyst, eg., through base catalyzed Hofmann elimination. In the case of $\mathbf{2 i}$, addition of water after the reaction with subsequent filtration of the solidified reaction product gave $2 \mathbf{i}$ in sufficient purity. Also, in those cases, where 2-phenylpropanol was used as the alcohol component were the products in sufficient purity that they could be used further in a subsequent transformation. These consecutive, but one-pot reactions are described below. For the other ether products, simple chromatography on silica gel provided the compounds with high purity.

As the authors have investigated previously one-pot transformations [9-13], where in addition to a metal catalyzed C-C bond forming reactions, another reaction was performed consecutively, such as a Wittig reaction, we were interested to find out whether an etherification could be performed in a onepot methodology with a metal catalyzed Suzuki-Miyaura coupling reaction, given the fact that the 
ethers provided in the reactions above were of sufficient purity. In addition, it must be stated that Jeffery had communicated reaction conditions for Pd-catalysed Heck reactions $[14,15]$ that are close to the reaction conditions that we had used for the etherification above, namely the performing of these reactions with Pd on carbon catalyst under solventless conditions, while using an ammonium salt as a phase transfer catalyst. The reaction of 3-bromo- and 4-bromobenzyl bromides $\mathrm{xx}$ and $\mathrm{xx}$ with 4methoxyboronic acid and 2-phenylethanol under $\mathrm{Pd} / \mathrm{C}$ (5wt\% Pd on carbon, Aldrich) catalysis in the presence of benzyltributylammonium bromide (BTBAC) at $75{ }^{\circ} \mathrm{C}$ for $24 \mathrm{~h}$ led to the desired products 5a and $\mathbf{5 b}$ in $69 \%$ and $70 \%$ isolated yields (Scheme 2). The reactions were carried out under normal atmosphere, ie., obviating the use of inert gases.<smiles>CC(C)(C)c1ccccc1-c1ccccc1</smiles>

2f<smiles>Brc1ccc(COCCc2ccccc2)cc1</smiles>

$2 \mathbf{i}$ 4b

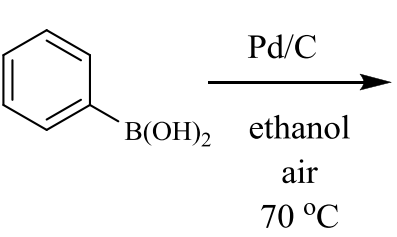

4b 5e $(80 \%)$

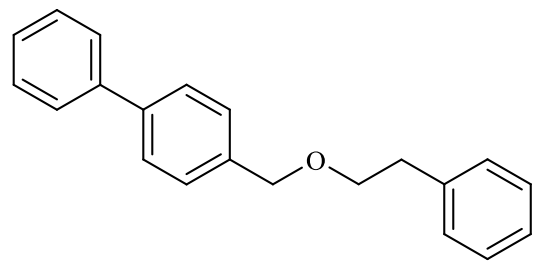

$5 d(27 \%)$

\section{Scheme 3}

Less stabilized arylboronic acids, ie., arylboronic acids with electron-withdrawing groups such as 3formyl-4-methoxyboronic acid, led to much lower yields of product, where the main compounds gained from the reactions were the bromobenzyl ethyl ethers 2 , indicating that the Suzuki reaction proceeded sluggishly (Scheme 2). Also, the employment of phenylboronic acid gave the cross coupling products only in low yield (Scheme 2).

In order to understand whether the low yields were associated with the conditions used, ie., with the solventless conditions, apart from 2-phenylethanol as an added reagent, or with the BTBAC added as a catalyst, Suzuki-Miyaura cross-coupling reactions were run with the $\mathrm{Pd} / \mathrm{C}$ catalyst utilized above in ethanol as solvent. Previously, the authors had run Suzuki-Miyaura reactions under similar conditions [16], albeit under inert atmosphere (see for instance the transformation of $\mathbf{2 f}$ to $\mathbf{5 e}$ ). In contrast to the results found at that time, the yields of Suzuki coupling products (2i, phenylboronic acid, Pd/C, ethanol, air) remained low (Scheme 3). Before, the Thiemann group had noted that newly opened, commercial Pd on activated carbon catalyst loses quickly its activity in Suzuki-Miyaura cross-coupling reactions, when stored under air. So, this may have contributed to the low yields above, when employing Pd/C in Suzuki-Miyaura reactions with non-alkoxy-substituted arylboronic acids under air. 
<smiles>Brc1ccc(COCCc2ccccc2)cc1</smiles>

$2 \mathbf{i}$<smiles>Brc1cccc(COCCc2ccccc2)c1</smiles>

2 i

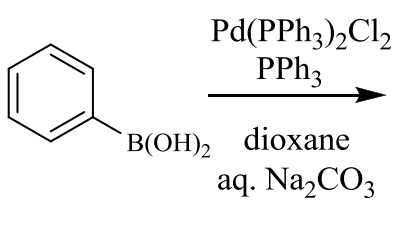

4b<smiles>c1ccc(CCOCc2ccc(-c3ccccc3)cc2)cc1</smiles>

5d $(86 \%)$

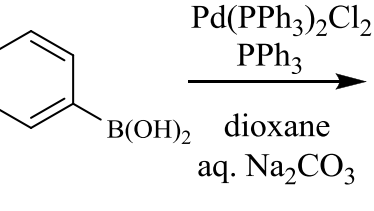

4b<smiles>c1ccc(CCOCc2cccc(-c3ccccc3)c2)cc1</smiles>

5f $(84 \%)$

Scheme 4

The same reactions carried under biphasic conditions that the authors normally use $\left[\mathrm{Pd}\left(\mathrm{PPh}_{3}\right)_{4}, \mathrm{PPh}_{3}\right.$, aq. $\mathrm{Na}_{2} \mathrm{CO}_{3}$ and an ether solvent such as DME, dioxane, or THF] the reaction yield for the biphenylated ethers $\mathbf{5 d}$ and $\mathbf{5 f}$ improved markedly (Scheme 4).<smiles>O=Cc1ccccc1-c1ccc(COCCc2ccccc2)cc1</smiles>

$5 g(87 \%)$

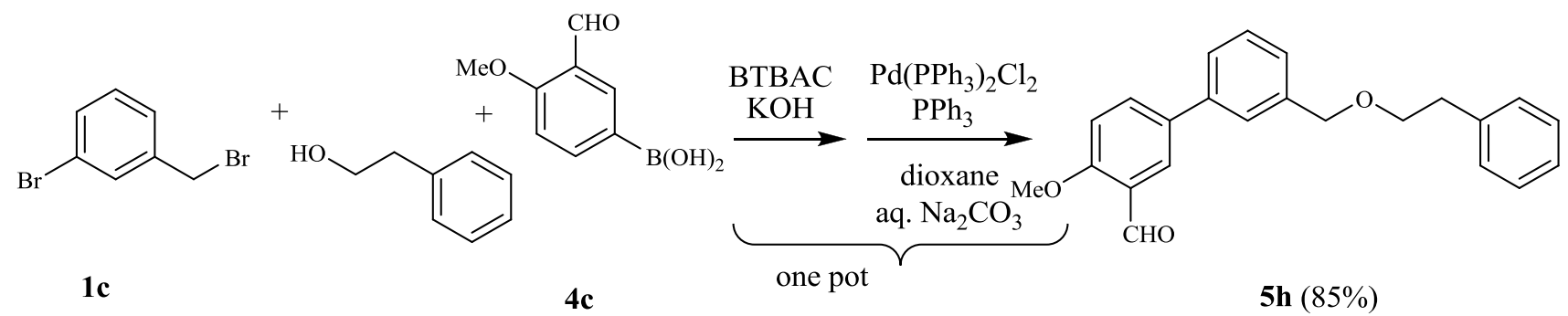

Scheme 5

To improve the yields of the coupling products with electron withdrawing substituents, while maintaining the strategy of a one-pot reaction, the authors decided to add small amounts of water and dioxane or THF as organic solvent, after completion of the solventless etherification. Furthermore, $\mathrm{Pd} / \mathrm{C}$ catalyst again was changed to $\mathrm{Pd}\left(\mathrm{PPh}_{3}\right)_{2} \mathrm{Cl}_{2} / \mathrm{PPh}_{3}$, based on the good results obtained above (Scheme 4). The difference between this methodology and the previously published procedures remains in the fact that while etherification and Suzuki-Miyaura coupling are carried out consecutively, they are still carried out in a one-pot procedure. With this new set of conditions, reactions could be carried out with both 3-bromobenzyl bromide (1c) and 4-bromobenzyl bromide (1a), arylboronic acids and 2-phenylethanol to give the biphenylmethyl phenylpropyl ethers $\mathbf{5 g}$ and $\mathbf{5 h}$ in good yield (Scheme 5). 
The formyl groups in $\mathbf{5 g}$ and $\mathbf{5 h}$ were reduced with $\mathrm{NaBH}_{4}$ in a solvent mixture $\mathrm{MeOH} /$ dioxane (or THF) to hydroxymethyl functions (Scheme 6). While $\mathbf{6 b}$ was purified by column chromatography on silica gel, it was ultimately seen, eg., in the case of $\mathbf{6 a}$, that no further purification was needed for employing 6a in the next step. Thus, after adding water to the reaction mixture, it was extracted with $\mathrm{CHCl}_{3}$, and the resulting organic phase to give the alcohol in sufficient purity. The alcohols were reacted subsequently with 4-bromobenzyl bromide to the bisethers $\mathbf{7 a}$ and $\mathbf{7 b}$ (Scheme 6) under the PTC conditions (BTBAC, ground $\mathrm{KOH}$ ) used previously (see above, Scheme 1). In these cases, the etherification was not carried out concurrently with the Suzuki-Miyaura coupling, due to the fact that the properties of the brominated diether $\mathbf{7 a}$ and $\mathbf{7 b}$ were to be scrutinized. In all fairness, it must be stated that the diether $\mathbf{7 b}$ was produced with small amounts of two not yet identified by-products, which necessitate column chromatographic separation. Whether a concurrent Suzuki cross coupling would lead to a more complex reaction mixture, will still need to be studied. As the alcohol $\mathbf{6 b}$ did not crystallize in our hands, the etherification to $\mathbf{7 b}$ was run at rt. On the other hand, alcohol $\mathbf{6 a}$ was gained as a solid. Thus, its etherification to $7 \mathbf{a}$ was run at $80{ }^{\circ} \mathrm{C}$ (Scheme 6).

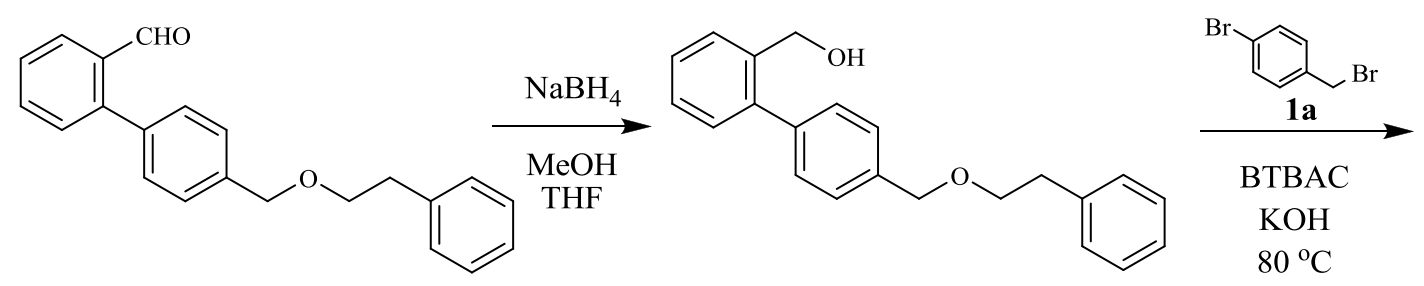

$5 g$

6a $97 \%$<smiles>Brc1ccc(COCc2ccccc2-c2ccc(COCc3ccccc3)cc2)cc1</smiles>

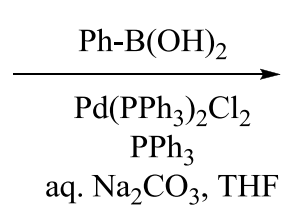

aq. $\mathrm{Na}_{2} \mathrm{CO}_{3}$, THF<smiles>c1ccc(CCOCc2ccc(-c3ccccc3COCc3ccc(-c4ccccc4)cc3)cc2)cc1</smiles>

$8 \mathbf{a}$

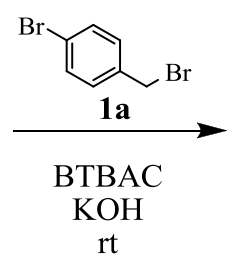

$5 \mathbf{h}$<smiles>COc1ccc(-c2cccc(COCCc3ccccc3)c2)cc1CO</smiles>

HO

$\mathrm{CHO}$

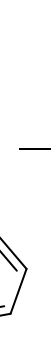

$\frac{\mathrm{Ph}}{\mathrm{Pd}}$

7b $83 \%$

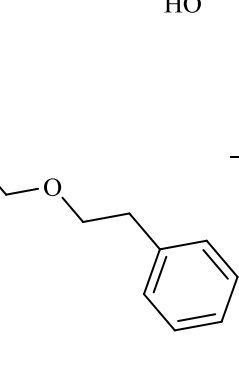

$\mathrm{Ph}-\mathrm{B}(\mathrm{OH})_{2}$
$\mathrm{Pd}\left(\mathrm{PPh}_{3}\right)_{2} \mathrm{Cl}_{2}$
$\mathrm{PPh}_{3}$
$\mathrm{Na}_{2} \mathrm{CO}_{3}, \mathrm{TH}$<smiles>C=CC=C(C)C</smiles>

8b $95 \%$ 


\section{Estimation of physical and thermal properties and relation to measured values:}

According to the interest in enhancing of the thermal and physical properties of the synthesized HTFs, a pre-study was performed to find some of these properties by group contribution estimation methods. There are different reported methods for estimation of properties of pure compounds such as Joback and Reid [18], Lydersen [19], Ambrose [20], Klincewicz and Reid [21], Lyman et al. [22], Horvath [23], and Marrero and Gani [24]. The chemical structure of pure compound is analyzed into different groups and based on the contribution of each group, the properties are calculated using certain formulas. In this work, the isobaric heat capacity of liquid $(\mathrm{Cp})$ is very important thermal property for calculations of enthalpy in heating and cooling processes. According to a three-level group contribution method reported by Kolsk et al. [25], the heat capacity as a function of temperature $\left(\mathrm{C}_{p}^{l}(T)\right)$ was estimated for all synthesized ethers by two approaches (Nonhierarchic (NH) and Hierarchic $(\mathrm{H}))$ using the following formulas:

$$
C_{p}^{l}(T)=C_{p 0}^{l}(T)+\sum_{i} N_{i} C_{p 1-i}^{l}(T)+w \sum_{j} M_{j} C_{p 2-j}^{l}(T)+z \sum_{k} O_{k} C_{p 3-k}^{l}(T)
$$

with

$$
C_{p q^{t h} \text { level }-i, j, \text { or } k}^{l}(T)=a_{q-i, j, \text { or } k}+b_{q-i, j, \text { or } k}\left(\frac{T}{100}\right)+d_{q-i, j, \text { or } k}\left(\frac{T}{100}\right)^{2}
$$

Where in eq. (1): $C_{p 1-i}^{l}(T)$ is the contribution of the first-level group of type $i, C_{p 2-j}^{l}(T)$ is the contribution of the second-level group of type $j$, and $C_{p 3-k}^{l}(T)$ is the contribution of the third-level group of type $k . N_{i}, M_{j}$, and $O_{k}$ indicate to the number of occurrences of the individual groups (of type $i, j$, or $k$, respectively) in a compound. $C_{p 0}^{l}(T)$ (which could be considered as the contribution of the zero-level group) is an additional adjustable parameter. Variables $w$ and $z$ are weighting factors that are assigned to 0 or 1 , depending on whether the second-level and third-level contributions, respectively, are used or not. In eq. (2), $a_{q-i, j, \text { or } k}, b_{q-i, j \text {, or } k}$, and $d_{q-i, j \text {, or } k}$ are adjustable parameters for the temperature dependence of $C_{p 0}^{l}(T), C_{p 1-i}^{l}(T), C_{p 2-j}^{l}(T)$, and $C_{p 3-k}^{l}(T)$.

Other physical properties such as melting point $\left(T_{m}\right)$, boiling point $\left(T_{b}\right)$, and critical temperature $\left(T_{c}\right)$ were estimated using Marrero and Gani’s model [24] according to the equations:

Normal melting point $\left(T_{m}\right): \exp \left(\frac{T_{m}}{T_{m 0}}\right)=\sum_{i} N_{i} T_{m 1 i}+\sum_{j} M_{j} T_{m 2 j}+\sum_{k} O_{k} T_{m 3 k}$

Normal boiling point $\left(T_{b}\right): \exp \left(\frac{T_{b}}{T_{b 0}}\right)=\sum_{i} N_{i} T_{b 1 i}+\sum_{j} M_{j} T_{b 2 j}+\sum_{k} O_{k} T_{b 3 k}$

Critical temperature $\left(T_{c}\right): \exp \left(\frac{T_{c}}{T_{c 0}}\right)=\sum_{i} N_{i} T_{c 1 i}+\sum_{j} M_{j} T_{c 2 j}+\sum_{k} O_{k} T_{c 3 k}$ 
The symbols in eq. (3, 4 and 5) $T_{\mathrm{m} 1 i}, T_{\mathrm{b} 1 i}$ and $T_{\mathrm{c} 1 i}$ represent the contributions $(i)$ of the first-order groups for the corresponding properties. Similarly, $T_{m 2 j}, T_{b 2 j}$ and $T_{c 2 j}$ and $T_{m 3 k}, T_{b 3 k}$ and $T_{c 3 k}$ represent the contributions $(j)$ and $(k)$ of the second and third-order groups, respectively. The $T_{m 0}, T_{b 0}$ and $T_{c 0}$ are additional adjustable parameters of the estimation models. $N_{i}, M_{j}$, and $O_{k}$ indicate to the number of occurrences of the individual groups (of type $i, j$, or $k$, respectively) in a compound.

The following table shows some estimated properties according to the methods [24] and [25], noting that the heat capacity is estimated at $300 \mathrm{~K}$ :

Table. 1: Computed physical and Thermal properties.

\begin{tabular}{|c|c|c|c|c|c|}
\hline \multirow{2}{*}{ Compound } & \multicolumn{2}{|c|}{$\mathrm{Cp}[\mathrm{J} /(\mathrm{mole} . \mathrm{K})](\mathrm{J} /(\mathrm{g} . \mathrm{K})$} & $\mathrm{T}_{\mathrm{m}}\left({ }^{0} \mathrm{C}\right)$ & $\mathrm{T}_{\mathrm{b}}\left({ }^{0} \mathrm{C}\right)$ & \multirow{2}{*}{$\mathrm{T}_{\mathrm{c}}\left({ }^{0} \mathrm{C}\right)$} \\
\cline { 2 - 4 } & $(\mathrm{NH})$ Appr. & $(\mathrm{H})$ Appr. & & & \\
\hline $2 \mathrm{a}$ & $309.2(1.35)$ & $299.6(1.31)$ & 44 & 153 & 375 \\
\hline $2 \mathrm{~b}$ & $338.7(1.39)$ & $328.8(1.35)$ & 48 & 167 & 386 \\
\hline $2 \mathrm{c}$ & $368.2(1.43)$ & $358.0(1.39)$ & 52 & 181 & 398 \\
\hline $2 \mathrm{~d}$ & $397.7(1.47)$ & $387.1(1.43)$ & 56 & 194 & 408 \\
\hline $2 \mathrm{e}$ & $427.2(1.50)$ & $416.3(1.46)$ & 60 & 206 & 419 \\
\hline $2 \mathrm{f}$ & $349.1(1.33)$ & $332.8(1.26)$ & 94 & 221 & 441 \\
\hline $2 \mathrm{~g}$ & $348.9(1.26)$ & $346.9(1.25)$ & 37 & 205 & 424 \\
\hline $2 \mathrm{~h}$ & $327.9(1.78)$ & $311.5(1.69)$ & 69 & 188 & 391 \\
\hline $2 \mathrm{i}$ & $402.7(1.38)$ & $378.9(1.30)$ & 39 & 229 & 444 \\
\hline $2 \mathrm{j}$ & $403.1(1.38)$ & $379.4(1.30)$ & 7 & 228 & 443 \\
\hline $5 \mathrm{a}$ & $682.4(2.14)$ & $515.9(1.62)$ & 68 & 252 & 500 \\
\hline $5 \mathrm{~b}$ & $682.0(2.14)$ & $515.4(1.62)$ & 90 & 253 & 500 \\
\hline $5 \mathrm{c}$ & $795.4(2.30)$ & $565.8(1.63)$ & 104 & 366 & 614 \\
\hline $5 \mathrm{~d}$ & $568.7(1.97)$ & $464.8(1.61)$ & 65 & 240 & 492 \\
\hline $5 \mathrm{f}$ & $569.2(1.97)$ & $465.3(1.61)$ & 39 & 238 & 491 \\
\hline $5 \mathrm{~g}$ & $678.9(2.15)$ & $512.1(1.62)$ & 91 & 354 & 605 \\
\hline $5 \mathrm{~h}$ & $795.8(2.30)$ & $566.3(1.63)$ & 84 & 365 & 614 \\
\hline $8 \mathrm{a}$ & $950.5(1.96)$ & $764.8(1.58)$ & 132 & 440 & 706 \\
\hline $8 \mathrm{~b}$ & $1067.4(2.07$ & $819.1(1.59)$ & 127 & 447 & 712 \\
\hline
\end{tabular}

It must be noted that according to the table, the specific heat capacities of the extended ethers $\mathbf{8}$ are appreciably high. Experimental and measured specific capacities have been found in agreement. Thus, experimentally, the specific heat capacity of $\mathbf{2 d}$ was measured to be $1.35 \mathrm{~J} / \mathrm{g} \cdot \mathrm{K}$.

For the melting points, it can be said that for simple molecules, there was a good agreement between the calculated and measured values. For the extended ethers, this does not hold true. Most likely, due to their complicated geometric structure molecular packing is frustrated, and so these ethers are liquids at room temperature. Density measurements have shown that up to $90{ }^{\circ} \mathrm{C}$, there is a linear relationship between the density and temperature, with a decrease in density with an increase of temperature. 
Importantly, Thermal Gravimetric Analysis (TGA) has shown that especially the extended ethers such as $\mathbf{8 b}$ are stable up to $300{ }^{\circ} \mathrm{C}$, even in air.

\section{Experimental Section}

General. - Melting points were measured with a Stuart SMP10 melting point apparatus and are uncorrected. ${ }^{1} \mathrm{H}$ NMR (at $400 \mathrm{MHz}$ ) and ${ }^{13} \mathrm{C}$ NMR (at $100.5 \mathrm{MHz}$ ) spectra were taken on a Varian 400 $\mathrm{MHz}$ spectrometer. IR measurements were performed on a Thermo Nicolet FT-IR spectrometer, model Nexus 470. Density measurements were performed on an Anton-Barr DMA 4500M densitometer. TGA measurements were carried out with a Shimadzu TGA-50. Column chromatography was executed on silica gel S (Riedel de Haen) and on silica gel (Merck grade 9385).

Triphenylphosphine (Sigma-Aldrich), 4-bromobenzyl bromide (1a) (Fluka), 3-bromobenzyl bromide (1c) (Aldrich), propanol (J. T. Baker), 1-butanol, 1-pentanol (Fluka), 1-hexanol (Merck Schuchardt), 1heptanol (Riedel de Haen), benzyl alcohol (Fluka), 2-phenylethanol (Merck-Schuchardt), benzyltrimethylammonium iodide (BTEAI) (Fluka), benzyltributyl ammonium chloride (BTBAC) (Fluka), potassium hydroxide (KOH) (UNI-Chem), phenylboronic acid (Aldrich), 4methoxyphenylboronic acid (Aldrich), 3-formyl-4-methoxyboronic acid (Aldrich), bis(triphenylphosphine)palladium(II) dichloride (TCI), palladium on carbon (5 wt\% Pd on activated carbon, Aldrich) were acquired commercially and used without further purification.

Selected procedures and spectroscopic data for the compounds prepared. -

General procedure A - solventless etherification under PTC conditions: Synthesis of 4-bromobenzyl $n$ propyl ether (2a): A mixture of 4-bromobenzyl bromide (1a) (2.0 g, $8.0 \mathrm{mmol}$ ), 1-propanol (1.44 g, 24 $\mathrm{mmol})$, finely ground $\mathrm{KOH}(0.67 \mathrm{~g}, 12 \mathrm{mmol})$ and BTEAI (130 mg, $0.4 \mathrm{mmol})$ of BTEAI was left under stirring at rt. for $16 \mathrm{hrs}$. Then, $\mathrm{CH}_{2} \mathrm{Cl}_{2}(2 \mathrm{X} 30 \mathrm{~mL})$ was added, and the mixture was extracted with water $(40 \mathrm{~mL})$. The organic phase was dried over $\mathrm{MgSO}_{4}$. After concentration in vacuo, the organic residue is filtered over a column (benzene/hexane, $1: 3$ ) to give 4-bromobenzyl $n$-propyl ether (2a) $(1.59 \mathrm{~g}, 87 \%)$ as a colorless oil; $\delta_{\mathrm{H}}\left(400 \mathrm{MHz}_{\mathrm{CDCl}}\right) 0.93\left(3 \mathrm{H}, \mathrm{t},{ }^{3} \mathrm{~J}=7.2 \mathrm{~Hz}, \mathrm{CH}_{3}\right), 1.62(2 \mathrm{H}$, $\left.\mathrm{qt},{ }^{3} J=7.2 \mathrm{~Hz},{ }^{3} J=6.8 \mathrm{~Hz}\right), 3.41\left(2 \mathrm{H}, \mathrm{t},{ }^{3} J=6.8 \mathrm{~Hz}, \mathrm{OCH}_{2}\right), 4.44\left(2 \mathrm{H}, \mathrm{s}, \mathrm{OCH}_{2}\right), 7.21\left(2 \mathrm{H}, \mathrm{d},{ }^{3} J=8.4\right.$ $\mathrm{Hz}), 7.45\left(2 \mathrm{H}, \mathrm{d},{ }^{3} J=8.4 \mathrm{~Hz}\right) ; \delta_{\mathrm{C}}\left(100.5 \mathrm{MHz}, \mathrm{CDCl}_{3}\right) 10.6\left(\mathrm{CH}_{3}\right), 22.9\left(\mathrm{CH}_{2}\right), 72.0\left(\mathrm{OCH}_{2}\right), 72.2$ $\left(\mathrm{OCH}_{2}\right), 121.3\left(\mathrm{C}_{\text {quat }}\right), 129.2(2 \mathrm{C}, \mathrm{CH}), 131.4(2 \mathrm{C}, \mathrm{CH}), 137.8\left(\mathrm{C}_{\text {quat }}\right)$.

4-Bromobenzyl $n$-butyl ether (2b): Following general procedure A and using $n$-butanol (1.77 g, 24 mmol), 1a was converted in $15 \mathrm{~h}$. to 4-bromobenzyl $n$-butyl ether (2b) (1.71 g, 88\% yield) as a colorless oil; $\delta_{\mathrm{H}}\left(400 \mathrm{MHz}, \mathrm{CDCl}_{3}\right) 0.91\left(3 \mathrm{H}, \mathrm{t},{ }^{3} \mathrm{~J}=7.4 \mathrm{~Hz}, \mathrm{CH}_{3}\right), 1.36-1.39(2 \mathrm{H}, \mathrm{m}), 1.56-1.59$ $(2 \mathrm{H}, \mathrm{m}), 3.45\left(2 \mathrm{H}, \mathrm{t},{ }^{3} \mathrm{~J}=6.6 \mathrm{~Hz}, \mathrm{OCH}_{2}\right), 4.44\left(2 \mathrm{H}, \mathrm{s}, \mathrm{OCH}_{2}\right), 7.20\left(2 \mathrm{H}, \mathrm{d},{ }^{3} J=8.4 \mathrm{~Hz}\right), 7.45\left(2 \mathrm{H}, \mathrm{d},{ }^{3} J\right.$ $=8.4 \mathrm{~Hz}) ; \delta_{\mathrm{C}}\left(100.5 \mathrm{MHz}, \mathrm{CDCl}_{3}\right) 13.9\left(\mathrm{CH}_{3}\right), 19.4\left(\mathrm{CH}_{2}\right), 31.8\left(\mathrm{CH}_{2}\right), 70.3\left(\mathrm{OCH}_{2}\right), 72.1\left(\mathrm{OCH}_{2}\right)$, $121.3\left(\mathrm{C}_{\text {quat }}\right), 129.2(2 \mathrm{C}, \mathrm{CH}), 131.4(2 \mathrm{C}, \mathrm{CH}), 137.8\left(\mathrm{C}_{\text {quat }}\right)$. 
4-Bromobenzyl $n$-heptyl ether (2e): Following general procedure A and using $n$-heptanol (2.8 g, 24 mmol), 1a was converted in $19 \mathrm{~h}$ to 4-bromobenzyl $n$-heptyl ether (2e) (1.96 g, 86\% yield) as a colorless oil; $\delta_{\mathrm{H}}\left(400 \mathrm{MHz}, \mathrm{CDCl}_{3}\right) 0.87\left(3 \mathrm{H}, \mathrm{t},{ }^{3} \mathrm{~J}=6.8 \mathrm{~Hz}, \mathrm{CH}_{3}\right), 1.24-1.38(8 \mathrm{H}, \mathrm{m}), 1.60\left(2 \mathrm{H}, \mathrm{tt},{ }^{3} \mathrm{~J}\right.$ $\left.=6.6,{ }^{3} J=6.6 \mathrm{~Hz}\right), 3.44\left(2 \mathrm{H}, \mathrm{t},{ }^{3} J=6.6 \mathrm{~Hz}\right), 4.44\left(2 \mathrm{H}, \mathrm{s}, \mathrm{OCH}_{2}\right), 7.20\left(2 \mathrm{H}, \mathrm{d},{ }^{3} J=8.0 \mathrm{~Hz}\right), 7.45(2 \mathrm{H}$, $\left.\mathrm{d},{ }^{3} J=8.0 \mathrm{~Hz}\right) ; \delta_{\mathrm{C}}\left(100.5 \mathrm{MHz}, \mathrm{CDCl}_{3}\right) 14.1\left(\mathrm{CH}_{3}\right), 22.6\left(\mathrm{CH}_{2}\right), 26.1\left(\mathrm{CH}_{2}\right), 29.1\left(\mathrm{CH}_{2}\right), 29.7\left(\mathrm{CH}_{2}\right)$, $31.8\left(\mathrm{CH}_{2}\right), 70.6\left(\mathrm{OCH}_{2}\right), 72.1\left(\mathrm{OCH}_{2}\right), 121.3\left(\mathrm{C}_{\text {quat }}\right), 129.2(2 \mathrm{C}, \mathrm{CH}), 131.4(2 \mathrm{C}, \mathrm{CH}), 137.7\left(\mathrm{C}_{\text {quat }}\right)$.

4-Bromobenzyl $n$-hexyl ether (2d): Modified procedure A' (scaled-up procedure A): To a mixture of 4-bromobenzyl bromide (1a) (6.0 g, $24 \mathrm{mmol})$, $n$-hexanol (7.34 g, $72 \mathrm{mmol})$, and KOH (2.0 g, 36 mmol) was added BTEAI (490 mg, $1.2 \mathrm{mmol}, 5 \mathrm{~mol} \%$ of 1a). The resulting reaction mixture was left to stir at rt. for $17 \mathrm{hrs}$. Then, $\mathrm{CH}_{2} \mathrm{Cl}_{2}(3 \mathrm{X} 25 \mathrm{~mL})$ was added, and the mixture was extracted with water $(50 \mathrm{~mL})$. The organic phase was dried over anhydrous $\mathrm{MgSO}_{4}$. After concentration in vacuo, the organic residue was filtered over a column (benzene/hexane, 1:3) to give 4-bromobenzyl $n$-hexyl ether (2d) $(5.72 \mathrm{~g}, 88 \%)$ as a colorless oil; $\delta_{\mathrm{H}}\left(400 \mathrm{MHz}, \mathrm{CDCl}_{3}\right) 0.88\left(3 \mathrm{H}, \mathrm{t},{ }^{3} \mathrm{~J}=6.8 \mathrm{~Hz}, \mathrm{CH}_{3}\right), 1.24-1.38$ $(6 \mathrm{H}, \mathrm{m}), 1.55-1.63(2 \mathrm{H}, \mathrm{m}), 3.44\left(2 \mathrm{H}, \mathrm{t},{ }^{3} J=6.8 \mathrm{~Hz}, \mathrm{OCH}_{2}\right), 4.44\left(2 \mathrm{H}, \mathrm{s}, \mathrm{OCH}_{2}\right), 7.20\left(2 \mathrm{H}, \mathrm{d},{ }^{3} J=\right.$ $8.0 \mathrm{~Hz}), 7.45\left(2 \mathrm{H}, \mathrm{d},{ }^{3} J=8.0 \mathrm{~Hz}\right) ; \delta_{\mathrm{C}}\left(100.5 \mathrm{MHz}, \mathrm{CDCl}_{3}\right) 14.0\left(\mathrm{CH}_{3}\right), 22.6\left(\mathrm{CH}_{2}\right), 25.8\left(\mathrm{CH}_{2}\right), 26.7$ $\left(\mathrm{CH}_{2}\right), 31.7\left(\mathrm{CH}_{2}\right), 70.7\left(\mathrm{OCH}_{2}\right), 72.1\left(\mathrm{OCH}_{2}\right), 121.3\left(\mathrm{C}_{\text {quat }}\right), 129.2(2 \mathrm{C}, \mathrm{CH}), 131.4(2 \mathrm{C}, \mathrm{CH}), 137.8$ $\left(\mathrm{C}_{\text {quat }}\right)$.

4-Bromobenzyl $n$-pentyl ether (2c): Following general procedure $\mathrm{A}^{\prime}$ and using $n$-pentanol (6.34 g, 72 mmol), 1a was converted in $29 \mathrm{~h}$ to 4-bromobenzyl $n$-pentyl ether (2c) $(5.30 \mathrm{~g}, 86 \%)$ as a colorless oil; $\delta_{\mathrm{H}}\left(400 \mathrm{MHz}, \mathrm{CDCl}_{3}\right) 0.89\left(3 \mathrm{H}, \mathrm{t},{ }^{3} J=7.0 \mathrm{~Hz}, \mathrm{CH}_{3}\right), 1.31-1.35(4 \mathrm{H}, \mathrm{m}), 1.60(2 \mathrm{H}, \mathrm{m}), 3.44\left(2 \mathrm{H}, \mathrm{t},{ }^{3} J\right.$ $\left.=6.6 \mathrm{~Hz}, \mathrm{OCH}_{2}\right), 4.44\left(2 \mathrm{H}, \mathrm{s}, \mathrm{OCH}_{2}\right), 7.20\left(2 \mathrm{H}, \mathrm{d},{ }^{3} J=7.8 \mathrm{~Hz}\right), 7.45\left(2 \mathrm{H}, \mathrm{d},{ }^{3} J=7.8 \mathrm{~Hz}\right) ; \delta_{\mathrm{C}}(100.5$ $\left.\mathrm{MHz}, \mathrm{CDCl}_{3}\right) 14.0\left(\mathrm{CH}_{3}\right), 22.5\left(\mathrm{CH}_{2}\right), 28.3\left(\mathrm{CH}_{2}\right), 29.4\left(\mathrm{CH}_{2}\right), 70.6\left(\mathrm{OCH}_{2}\right), 72.1\left(\mathrm{OCH}_{2}\right), 121.3$ $\left(\mathrm{C}_{\text {quat }}\right), 129.2(2 \mathrm{C}, \mathrm{CH}), 131.4(2 \mathrm{C}, \mathrm{CH}), 137.7\left(\mathrm{C}_{\text {quat }}\right)$.

4-Bromobenzyl benzyl ether (2g): Following general procedure A' and using benzyl alcohol (7.8 g, 72 $\mathrm{mmol})$, 1a was converted in $17 \mathrm{~h}$ to 4-bromobenzyl benzyl ether $(\mathbf{2 g})(6.05 \mathrm{~g}, 91 \%)$ as a colorless oil; $\delta_{\mathrm{H}}\left(400 \mathrm{MHz}, \mathrm{CDCl}_{3}\right) 4.42\left(2 \mathrm{H}, \mathrm{s}, \mathrm{OCH}_{2}\right), 4.47\left(2 \mathrm{H}, \mathrm{s}, \mathrm{OCH}_{2}\right), 7.15\left(2 \mathrm{H}, \mathrm{d},{ }^{3} J=9.0 \mathrm{~Hz}\right), 7.19-7.24$ $(3 \mathrm{H}, \mathrm{m}), 7.25-7.28(2 \mathrm{H}, \mathrm{m}), 7.39\left(2 \mathrm{H}, \mathrm{d},{ }^{3} J=9.0 \mathrm{~Hz}\right) ; \delta_{\mathrm{C}}\left(100.5 \mathrm{MHz}, \mathrm{CDCl}_{3}\right) 71.3\left(\mathrm{OCH}_{2}\right), 72.2$ $\left(\mathrm{OCH}_{2}\right), 121.5\left(\mathrm{C}_{\text {quat }}\right), 127.8(\mathrm{CH}), 127.8(2 \mathrm{C}, \mathrm{CH}), 128.5(2 \mathrm{C}, \mathrm{CH}), 129.4(2 \mathrm{C}, \mathrm{CH}), 131.5(2 \mathrm{C}, \mathrm{CH})$, $137.3\left(\mathrm{C}_{\text {quat }}\right), 138.0\left(\mathrm{C}_{\text {quat }}\right)$.

Benzyl phenyl ether (2h): To a mixture of benzyl chloride (1b) $(2.0 \mathrm{~g}, 15.0 \mathrm{mmol})$, phenol (1.8 g, 19 mmol), and $\mathrm{KOH}(1.8 \mathrm{~g}, 32 \mathrm{mmol})$ was added BTEAI (244 mg, $0.75 \mathrm{mmol}, 5 \mathrm{~mol} \%$ of 1b). The resulting reaction mixture was stirred at $65{ }^{\circ} \mathrm{C}$ for $20 \mathrm{hrs}$. Then, $\mathrm{CH}_{2} \mathrm{Cl}_{2}(2 \mathrm{X} 30 \mathrm{~mL})$ was added, and the mixture was extracted with water $(40 \mathrm{~mL})$. The organic phase was dried over anhydrous $\mathrm{MgSO}_{4}$. After concentration in vacuo, the organic residue was filtered over a column (benzene/hexane, 1:3) to give benzyl phenyl ether $(\mathbf{2 h})(2.15 \mathrm{~g}, 78 \%)$ as a slowly crystallizing solid; $\delta_{\mathrm{H}}\left(400 \mathrm{MHz}, \mathrm{CDCl}_{3}\right) 5.10$ $\left(2 \mathrm{H}, \mathrm{s}, \mathrm{OCH}_{2}\right), 6.94-7.00(3 \mathrm{H}, \mathrm{m}), 7.25(2 \mathrm{H}, \mathrm{s}, \mathrm{CH}), 7.27-7.45(5 \mathrm{H}, \mathrm{m}) ; \delta_{\mathrm{C}}\left(100.5 \mathrm{MHz}, \mathrm{CDCl}_{3}\right)$ 
$69.9\left(\mathrm{OCH}_{2}\right), 114.8(2 \mathrm{C}, \mathrm{CH}), 120.9(\mathrm{CH}), 127.5(2 \mathrm{C}, \mathrm{CH}), 127.9(\mathrm{CH}), 128.6(2 \mathrm{C}, \mathrm{CH}), 129.5(2 \mathrm{C}$, $\mathrm{CH}), 137.0\left(\mathrm{C}_{\text {quat }}\right), 158.8\left(\mathrm{C}_{\text {quat }}\right)$.

4-Bromobenzyl phenylethyl ether (2i): General Procedure C: To a mixture of 4-bromobenzyl bromide (1a) $(2.25 \mathrm{~g}, 9 \mathrm{mmol})$, 2-phenylethanol $(1.0 \mathrm{~g}, 8.2 \mathrm{mmol})$, and KOH (1.0 g, $17.8 \mathrm{mmol})$ was added BTBAC (280 mg, $0.9 \mathrm{mmol}, 10 \mathrm{~mol} \%$ of $\mathbf{1 a}$ ). The resulting reaction mixture was left to stir at $\mathrm{rt}$. for $17.5 \mathrm{hrs}$. Then, water $(60 \mathrm{~mL})$ was added to the reaction mixture. The product $(\mathbf{2 i})$, as a colorless precipitate, was filtered and washed with methanol $(10 \mathrm{~mL})$, yielding $2 \mathbf{i}(1.7 \mathrm{~g}, 71 \%)$ as a colorless solid, m.p. 47-49 ${ }^{0} \mathrm{C} . v_{\max }\left(\mathrm{KBr} / \mathrm{cm}^{-1}\right) 3466,3084,2942,2852,1591,1488,1453,1391,1357,1120$, 1011, 834, 750, 495; $\delta_{\mathrm{H}}\left(400 \mathrm{MHz}, \mathrm{CDCl}_{3}\right) 2.92\left(2 \mathrm{H}, \mathrm{t},{ }^{3} \mathrm{~J}=7.0 \mathrm{~Hz}\right), 3.67\left(2 \mathrm{H}, \mathrm{t},{ }^{3} \mathrm{~J}=7.2 \mathrm{~Hz}\right), 4.46$ $\left(2 \mathrm{H}, \mathrm{s}, \mathrm{OCH}_{2}\right), 7.15\left(2 \mathrm{H}, \mathrm{d},{ }^{3} J=8.0 \mathrm{~Hz}\right), 7.20-7.23(2 \mathrm{H}, \mathrm{m}), 7.26\left(\mathrm{H}, \mathrm{d},{ }^{3} J=8.0 \mathrm{~Hz}\right), 7.29-7.31(2 \mathrm{H}$, m), $7.44\left(2 \mathrm{H}, \mathrm{d},{ }^{3} J=8.0 \mathrm{~Hz}\right) ; \delta_{\mathrm{C}}\left(100.5 \mathrm{MHz}, \mathrm{CDCl}_{3}\right) 36.3\left(\mathrm{CH}_{2}\right), 71.3\left(\mathrm{OCH}_{2}\right), 72.2\left(\mathrm{OCH}_{2}\right), 121.3$ $\left(\mathrm{C}_{\text {quat }}\right), 126.3(\mathrm{CH}), 128.4(2 \mathrm{C}, \mathrm{CH}), 128.9(2 \mathrm{C}, \mathrm{CH}), 129.2(2 \mathrm{C}, \mathrm{CH}), 131.4(2 \mathrm{C}, \mathrm{CH}), 137.4\left(\mathrm{C}_{\text {quat }}\right)$, 138.8 ( $\left.\mathrm{C}_{\text {quat }}\right)$.

1,2-Bis((4-bromobenzyloxy)methyl)benzene (2k): To a mixture of 4-bromobenzyl bromide (1a) (4.0 g, $16 \mathrm{mmol})$, 1,2-phenylenedimethanol $(1.0 \mathrm{~g}, 7.5 \mathrm{mmol})$, and $\mathrm{KOH}(1.68 \mathrm{~g}, 30 \mathrm{mmol})$ was added BTBAC $\left(0.5 \mathrm{~g}, 1.6 \mathrm{mmol}, 10 \mathrm{~mol} \%\right.$ of 1a). The resulting reaction mixture was left to stir at $93{ }^{0} \mathrm{C}$ for $18.5 \mathrm{hrs}$. Then, $\mathrm{CH}_{2} \mathrm{Cl}_{2}(2 \mathrm{X} 30 \mathrm{~mL})$ was added, and the mixture was extracted with water $(40 \mathrm{~mL})$. The organic phase was dried over anhydrous $\mathrm{MgSO}_{4}$. The solvent was evaporated in vacuo. Thereafter, the product $(\mathbf{2 k})$ crystallized after addition of hexane $(10 \mathrm{~mL})$ to the organic residue, yielding $\mathbf{2 k}$ (3.29 g, 92\%) as a colorless solid, m.p. $48{ }^{\circ} \mathrm{C} ; \delta_{\mathrm{H}}\left(400 \mathrm{MHz}, \mathrm{CDCl}_{3}\right) 4.45\left(4 \mathrm{H}, \mathrm{s}, \mathrm{OCH}_{2}\right), 4.58(4 \mathrm{H}, \mathrm{s}$, $\left.\mathrm{OCH}_{2}\right), 7.19\left(2 \mathrm{H}, \mathrm{d},{ }^{3} J=8.0 \mathrm{~Hz}\right), 7.24\left(2 \mathrm{H}, \mathrm{d},{ }^{3} \mathrm{~J}=8.0 \mathrm{~Hz}\right), 7.30-7.32(2 \mathrm{H}, \mathrm{m}), 7.39-7.42(2 \mathrm{H}, \mathrm{m}), 7.45$ $\left(4 \mathrm{H}, \mathrm{d},{ }^{3} J=8.0 \mathrm{~Hz}\right) ; \delta_{\mathrm{C}}\left(100.5 \mathrm{MHz}, \mathrm{CDCl}_{3}\right) 69.9\left(2 \mathrm{C}, \mathrm{OCH}_{2}\right), 71.5\left(2 \mathrm{C}, \mathrm{OCH}_{2}\right), 121.5\left(2 \mathrm{C}, \mathrm{C}_{\text {quat }}\right)$, $128.0(2 \mathrm{C}, \mathrm{CH}), 129.0(2 \mathrm{C}, \mathrm{CH}), 129.4(4 \mathrm{C}, \mathrm{CH}), 131.5(4 \mathrm{C}, \mathrm{CH}), 136.2\left(2 \mathrm{C}, \mathrm{C}_{\text {quat }}\right), 137.2\left(2 \mathrm{C}, \mathrm{C}_{\text {quat }}\right)$.

3-Bromobenzyl phenylethyl ether $(\mathbf{2} \mathbf{j})$ - General procedure C: Column chromatography on silica gel $\left(\mathrm{CH}_{2} \mathrm{Cl}_{2}\right.$-hexane $\left.2: 1\right)$ gives $\mathbf{2 j}(73 \%)$ as a colorless oil; $v_{\max }$ (neat, $\left.\mathrm{cm}^{-1}\right)$ 3062, 3027, 2919, 2860, 1598, 1571, 1356, 1200, 1109, 777, 749, 698, 671; $\delta_{\mathrm{H}}\left(400 \mathrm{MHz}, \mathrm{CDCl}_{3}\right) 2.94\left(2 \mathrm{H}, \mathrm{t},{ }^{3} J=7.2 \mathrm{~Hz}\right)$, $3.69\left(2 \mathrm{H}, \mathrm{t},{ }^{3} \mathrm{~J}=7.2 \mathrm{~Hz}, \mathrm{OCH}_{2}\right), 4.48\left(2 \mathrm{H}, \mathrm{s}, \mathrm{OCH}_{2}\right), 7.17-7.32(7 \mathrm{H}, \mathrm{m}), 7.38-7.41(1 \mathrm{H}, \mathrm{m}), 7.44-$ $7.45(1 \mathrm{H}, \mathrm{m}) ; \delta_{\mathrm{C}}\left(100.5 \mathrm{MHz}, \mathrm{CDCl}_{3}\right) 36.3\left(\mathrm{CH}_{2}\right), 71.4\left(\mathrm{OCH}_{2}\right), 72.1\left(\mathrm{OCH}_{2}\right), 122.5\left(\mathrm{C}_{\text {quat }}\right), 125.9$ $(\mathrm{CH}), 126.3(\mathrm{CH}), 129.9(\mathrm{CH}), 130.5(\mathrm{CH}), 130.6(\mathrm{CH}), 128.4(2 \mathrm{C}, \mathrm{CH}), 128.9(2 \mathrm{C}, \mathrm{CH}), 138.8$ $\left(\mathrm{C}_{\text {quat }}\right), 140.8$ ( $\left.\mathrm{C}_{\text {quat }}\right)$.

4-Phenylbenzyl phenylethyl ether (5d) - General procedure D: A mixture of 4-bromobenzyl phenylethyl ether (2.22 g, $7.6 \mathrm{mmol})$, phenylboronic acid $(1.4 \mathrm{~g}, 11.4 \mathrm{mmol})$, solid $\mathrm{Na}_{2} \mathrm{CO}_{3}(750 \mathrm{mg}$, $7.14 \mathrm{mmol})$ and $\mathrm{Pd} / \mathrm{C}(150 \mathrm{mg}, 5 \mathrm{w} \% \mathrm{Pd})$ in $\mathrm{EtOH}(15 \mathrm{~mL})$ was stirred at $70{ }^{\circ} \mathrm{C}$ for $14 \mathrm{~h}$. Thereafter, the ethanol is evaporated in vacuo, and the residue subjected to column chromatography on silica gel (hexane-CH2Cl2 $3: 1$ ) to give 5d (590 mg, 27\%) as a colorless solid; mp. $68{ }^{\circ} \mathrm{C} ; v_{\max }$ (neat, $\mathrm{cm}^{-1}$ ) $3033,2913,2858,1486,1450,1401,1369,1118,1104,822,759,739,698 ; \delta_{\mathrm{H}}\left(400 \mathrm{MHz}, \mathrm{CDCl}_{3}\right)$ 
$2.96\left(2 \mathrm{H}, \mathrm{t},{ }^{3} J=7.2 \mathrm{~Hz}\right), 3.73\left(2 \mathrm{H}, \mathrm{d},{ }^{3} J=7.2 \mathrm{~Hz}, \mathrm{OCH}_{2}\right), 4.57\left(2 \mathrm{H}, \mathrm{s}, \mathrm{OCH}_{2}\right), 7.22-7.46(10 \mathrm{H}, \mathrm{m})$, $7.56\left(2 \mathrm{H}, \mathrm{d},{ }^{3} \mathrm{~J}=8.0 \mathrm{~Hz}\right), 7.59\left(2 \mathrm{H}, \mathrm{d},{ }^{3} \mathrm{~J}=8.0 \mathrm{~Hz}\right) ; \delta_{\mathrm{C}}\left(100.5 \mathrm{MHz}, \mathrm{CDCl}_{3}\right) 36.4\left(\mathrm{CH}_{2}\right), 71.3\left(\mathrm{OCH}_{2}\right)$, $72.7\left(\mathrm{OCH}_{2}\right), 126.2(\mathrm{CH}), 127.0(2 \mathrm{C}, \mathrm{CH}), 127.1(\mathrm{CH}), 127.2(2 \mathrm{C}, \mathrm{CH}), 128.1(2 \mathrm{C}, \mathrm{CH}), 128.4(2 \mathrm{C}$, $\mathrm{CH}), 128.7(2 \mathrm{C}, \mathrm{CH}), 129.0(2 \mathrm{C}, \mathrm{CH}), 137.4\left(\mathrm{C}_{\text {quat }}\right), 138.9\left(\mathrm{C}_{\text {quat }}\right), 140.5\left(\mathrm{C}_{\text {quat }}\right), 140.9\left(\mathrm{C}_{\text {quat }}\right)$.

3-Phenylbenzyl phenylethyl ether (5f) as a colorless oil; $v_{\max }$ (neat, $\mathrm{cm}^{-1}$ ) 3060, 3029, 2920, 2857, 1601, 1480, 1453, 1357, 1088, 1029, 755, 699; $\delta_{\mathrm{H}}\left(400 \mathrm{MHz}, \mathrm{CDCl}_{3}\right) 2.96\left(2 \mathrm{H}, \mathrm{t},{ }^{3} \mathrm{~J}=7.2 \mathrm{~Hz}\right), 3.73$ $\left(2 \mathrm{H}, \mathrm{t},{ }^{3} \mathrm{~J}=7.2 \mathrm{~Hz}, \mathrm{OCH}_{2}\right), 4.59\left(2 \mathrm{H}, \mathrm{s}, \mathrm{OCH}_{2}\right), 7.19-7.58(14 \mathrm{H}, \mathrm{m}) ; \delta_{\mathrm{C}}\left(100.5 \mathrm{MHz}, \mathrm{CDCl}_{3}\right) 36.4$ $\left(\mathrm{CH}_{2}\right), 71.3\left(\mathrm{OCH}_{2}\right), 72.9\left(\mathrm{OCH}_{2}\right), 126.2(\mathrm{CH}), 126.3(\mathrm{CH}), 126.4(\mathrm{CH}), 126.5(\mathrm{CH}), 127.2(2 \mathrm{C}, \mathrm{CH})$, $127.3(\mathrm{CH}), 128.3(2 \mathrm{C}, \mathrm{CH}), 128.7(2 \mathrm{C}, \mathrm{CH}), 128.8(\mathrm{CH}), 128.9(2 \mathrm{C}, \mathrm{CH}), 138.9\left(\mathrm{C}_{\text {quat }}\right), 139.0\left(\mathrm{C}_{\text {quat }}\right)$, $141.0\left(\mathrm{C}_{\text {quat }}\right), 141.3\left(\mathrm{C}_{\text {quat }}\right)$.

General procedure E - one-pot etherification - Suzuki-Miyaura cross coupling with $\mathrm{Pd} / \mathrm{C}$ as catalyst: 4-(4-Methoxyphenyl)benzyl phenylethyl ether (5b). - To a mixture of of 4-bromobenzyl bromide (1a) (2.25 g, $9.0 \mathrm{mmol})$, 2-phenylethanol $(1.0 \mathrm{~g}, 8.2 \mathrm{mmol})$, and $\mathrm{KOH}(1.0 \mathrm{~g}, 17.8 \mathrm{mmol})$ was added BTBAC (280 mg, $0.9 \mathrm{mmol}, 10 \mathrm{~mol} \%$ of 1a). The resulting reaction mixture was left under stirring at rt. for $20 \mathrm{hrs}$. Then 4-methoxyphenylboronic acid $(2.0 \mathrm{~g}, 13.2 \mathrm{mmol})$ was added to the reaction mixture, followed by $\mathrm{Pd} / \mathrm{C}(50 \mathrm{mg}, 5 \mathrm{wt} \%, 0.3$ atom $\% \mathrm{Pd}$ [based on phenylethanol]). The reaction mixture was stirred at $75{ }^{\circ} \mathrm{C}$ for a further $24 \mathrm{hr}$. Then, further $\mathrm{Pd} / \mathrm{C}(50 \mathrm{mg}, 5 \mathrm{wt} \%, 0.3$ atom\% $\mathrm{Pd}$ [based on phenylethanol]) was added to the reaction mixture, and the reaction was left for another 24 hr under the same conditions. The mixture was cooled, and $\mathrm{CH}_{2} \mathrm{Cl}_{2}(2 \mathrm{X} 30 \mathrm{~mL})$ was added, and the mixture was extracted with water $(40 \mathrm{~mL})$. The organic phase was dried over anhydrous $\mathrm{MgSO}_{4}$. After concentration in vacuo, the organic residue was filtered over silica gel (hexane $/ \mathrm{CH}_{2} \mathrm{Cl}_{2}, 1: 3$ ) to give 4(4-methoxyphenyl)benzyl phenylethyl ether (5b) $(1.83 \mathrm{~g}, 70 \%)$ as a white solid, $\mathrm{mp} 71{ }^{0} \mathrm{C} ; v_{\max }$ $\left(\mathrm{KBr} / \mathrm{cm}^{-1}\right) 2854,1607,1501,1110,1037,816,697 ; \delta_{\mathrm{H}}\left(400 \mathrm{MHz}, \mathrm{CDCl}_{3}\right) 2.96\left(2 \mathrm{H}, \mathrm{t},{ }^{3} J=8.0 \mathrm{~Hz}\right)$, $372\left(2 \mathrm{H}, \mathrm{t},{ }^{3} J=8 \mathrm{~Hz}\right), 3.85\left(3 \mathrm{H}, \mathrm{s}, \mathrm{OCH}_{3}\right), 4.56\left(2 \mathrm{H}, \mathrm{s}, \mathrm{OCH}_{2}\right), 6.98\left(2 \mathrm{H}, \mathrm{d},{ }^{3} J=8.0 \mathrm{~Hz}\right), 7.22-7.36$ $(9 \mathrm{H}, \mathrm{m}), 7.52\left(2 \mathrm{H}, \mathrm{d},{ }^{3} J=8.0 \mathrm{~Hz}\right) ; \delta_{\mathrm{C}}\left(100.5 \mathrm{MHz}, \mathrm{CDCl}_{3}\right) 36.4\left(\mathrm{CH}_{2}\right), 55.3\left(\mathrm{OCH}_{3}\right), 71.3\left(\mathrm{OCH}_{2}\right)$, $72.7\left(\mathrm{OCH}_{2}\right), 114.2(2 \mathrm{C}, \mathrm{CH}), 126.2(\mathrm{CH}), 126.7(2 \mathrm{C}, \mathrm{CH}), 128.1(4 \mathrm{C}, \mathrm{CH}), 128.4(2 \mathrm{C}, \mathrm{CH}), 129.0$ $(2 \mathrm{C}, \mathrm{CH}), 133.5\left(\mathrm{C}_{\text {quat }}\right), 136.8\left(\mathrm{C}_{\text {quat }}\right), 138.9\left(\mathrm{C}_{\text {quat }}\right), 140.1\left(\mathrm{C}_{\text {quat }}\right), 159.1\left(\mathrm{C}_{\text {quat }}\right)$.

3-(4-Methoxyphenyl)benzyl phenylethyl ether (5a) as a colorless solid; mp. $70{ }^{\circ} \mathrm{C} ; v_{\max }$ (neat, $\mathrm{cm}^{-1}$ ) $1606,1518,1484,1292,1252,1184,1116,1028,836,790,744,699,571,498 ; \delta_{\mathrm{H}}\left(400 \mathrm{MHz}, \mathrm{CDCl}_{3}\right)$ $2.99\left(2 \mathrm{H}, \mathrm{t},{ }^{3} \mathrm{~J}=7.2 \mathrm{~Hz}\right), 3.75\left(2 \mathrm{H}, \mathrm{t},{ }^{3} J=7.2 \mathrm{~Hz}\right), 3.86\left(3 \mathrm{H}, \mathrm{s}, \mathrm{OCH}_{3}\right), 4.59\left(2 \mathrm{H}, \mathrm{s}, \mathrm{OCH}_{2}\right), 6.99(2 \mathrm{H}$, $\left.\mathrm{d},{ }^{3} \mathrm{~J}=8.8 \mathrm{~Hz}\right), 7.22-7.53(11 \mathrm{H}, \mathrm{m}) ; \delta_{\mathrm{C}}\left(100.5 \mathrm{MHz}, \mathrm{CDCl}_{3}\right) 36.4\left(\mathrm{CH}_{2}\right), 55.4\left(\mathrm{OCH}_{3}\right), 71.3\left(\mathrm{OCH}_{2}\right)$, $73.0\left(\mathrm{OCH}_{2}\right), 114.2(2 \mathrm{C}, \mathrm{CH}), 125.9(2 \mathrm{C}, \mathrm{CH}), 126.0(\mathrm{CH}), 126.1(\mathrm{CH}), 126.2(\mathrm{CH}), 128.2(2 \mathrm{C}, \mathrm{CH})$, $128.4(\mathrm{CH}), 128.8(\mathrm{CH}), 129.0(2 \mathrm{C}, \mathrm{CH}), 133.6\left(\mathrm{C}_{\text {quat }}\right), 138.9\left(\mathrm{C}_{\text {quat }}\right), 139.0\left(\mathrm{C}_{\text {quat }}\right), 140.9\left(\mathrm{C}_{\text {quat }}\right), 159.2$ $\left(\mathrm{C}_{\text {quat }}\right)$.

3-(3-Formyl-4-methoxyphenyl)benzyl phenylethyl ether (5h) - General procedure F - one-pot etherification - Suzuki coupling with $\mathrm{Pd}\left(\mathrm{PPh}_{3}\right)_{2} \mathrm{Cl}_{2}$ as catalyst: A mixture of 3-bromobenzyl bromide 
(1c) (1.54 g, $6.2 \mathrm{mmol})$, 2-phenylethanol (690 mg, $5.66 \mathrm{mmol}), \mathrm{KOH} \mathrm{(690} \mathrm{mg,} 12.3 \mathrm{mmol})$ and BTBAC (190 mg, $0.62 \mathrm{mmol})$ was stirred at $\mathrm{rt}$ for $18 \mathrm{~h}$. Then, water $(10 \mathrm{~mL})$ and dioxane $(10 \mathrm{~mL})$ were added. To this, were entered 3-formyl-4-methoxyphenylboronic acid (1.15 g, $6.39 \mathrm{mmol})$, $\mathrm{Pd}\left(\mathrm{PPh}_{3}\right)_{2} \mathrm{Cl}_{2}\left(30 \mathrm{mg}, 4.27 \cdot 10^{-5} \mathrm{~mol}\right)$, triphenylphosphine $\left(\mathrm{PPh}_{3}, 30 \mathrm{mg}, 0.11 \mathrm{mmol}\right)$. The resulting biphasic solution was heated to $75{ }^{\circ} \mathrm{C}$ and stirred for $14 \mathrm{~h}$. Thereafter, the reaction mixture was given into water $(20 \mathrm{~mL})$ and extracted with $\mathrm{CH}_{2} \mathrm{Cl}_{2}(2 \mathrm{X} 15 \mathrm{~mL})$ and $\mathrm{CHCl}_{3}(15 \mathrm{~mL})$. The organic phase was dried over anhydrous $\mathrm{MgSO}_{4}$ and evaporated in vacuo. The residue was subjected to column chromatography on silica gel (hexane/ether/ $\left.\mathrm{CHCl}_{3} 3: 1: 1\right)$ to give $\mathbf{5 h}(1.66 \mathrm{~g}, 85 \%)$ as a colorless oil; $v_{\max }\left(\right.$ neat $\left.\mathrm{cm}^{-1}\right)$ 3028, 2858, 1680, 1608, 1503, 1481, 1454, 1391, 1272, 1181, 1023, 789, 750, 700, 648; $\delta_{\mathrm{H}}\left(400 \mathrm{MHz}, \mathrm{CDCl}_{3}\right) 2.95\left(2 \mathrm{H}, \mathrm{t},{ }^{3} \mathrm{~J}=7.2 \mathrm{~Hz}, \mathrm{CH}_{2}\right), 3.74\left(2 \mathrm{H}, \mathrm{t},{ }^{3} J=7.2 \mathrm{~Hz}, \mathrm{OCH}_{2}\right), 3.98(3 \mathrm{H}$, s, $4.57\left(2 \mathrm{H}, \mathrm{s}, \mathrm{OCH}_{2}\right), 7.06\left(1 \mathrm{H}, \mathrm{d},{ }^{3} J=8.4 \mathrm{~Hz}\right), 7.39(1 \mathrm{H}, \mathrm{m}), 7.19-7.51(9 \mathrm{H}, \mathrm{m}), 7.75(1 \mathrm{H}, \mathrm{m}), 8.07$ $(1 \mathrm{H}, \mathrm{s}), 10.52(1 \mathrm{H}, \mathrm{s}, \mathrm{CHO}) ; \delta_{\mathrm{C}}\left(100.5 \mathrm{MHz}, \mathrm{CDCl}_{3}\right) 36.4\left(\mathrm{CH}_{2}\right), 55.8\left(\mathrm{OCH}_{3}\right), 71.4\left(\mathrm{OCH}_{2}\right), 72.9$ $\left(\mathrm{OCH}_{2}\right), 112.1(\mathrm{CH}), 124.9\left(\mathrm{C}_{\text {quat }}\right), 125.8(\mathrm{CH}), 125.9(\mathrm{CH}), 126.2(\mathrm{CH}), 126.5(\mathrm{CH}), 126.8(\mathrm{CH})$, $128.3(2 \mathrm{C}, \mathrm{CH}), 128.8(\mathrm{CH}), 128.9(2 \mathrm{C}, \mathrm{CH}), 133.6\left(\mathrm{C}_{\text {quat }}\right), 134.4(\mathrm{CH}), 138.6\left(\mathrm{C}_{\text {quat }}\right), 139.1\left(\mathrm{C}_{\text {quat }}\right)$, $139.6\left(\mathrm{C}_{\text {quat }}\right), 161.3\left(\mathrm{C}_{\text {quat }}\right), 189.8(\mathrm{CHO})$.

4-(2-Formylphenyl)benzyl phenylethyl ether (5g) as a colorless oil, prepared according general procedure F; $v_{\max }\left(\right.$ neat, $\mathrm{cm}^{-1}$ ) 3061, 3027, 2919, 2855, 2752, 1692, 1597, 1476, 1452, 1393, 1359, 1254, 1196, 1099, 1006, 828, 766, 700; $\delta_{\mathrm{H}}\left(400 \mathrm{MHz}, \mathrm{CDCl}_{3}\right) 2.97\left(2 \mathrm{H}, \mathrm{t},{ }^{3} J=6.8 \mathrm{~Hz}, \mathrm{CH}_{2}\right), 3.75$ $\left(2 \mathrm{H}, \mathrm{t},{ }^{3} \mathrm{~J}=6.8 \mathrm{~Hz}, \mathrm{CH}_{2}\right), 4.59\left(2 \mathrm{H}, \mathrm{s}, \mathrm{OCH}_{2}\right), 7.23-7.49(6 \mathrm{H}, \mathrm{m}), 7.34\left(2 \mathrm{H}, \mathrm{d},{ }^{3} J=8.0 \mathrm{~Hz}\right), 7.40(2 \mathrm{H}$, $\left.\mathrm{d},{ }^{3} \mathrm{~J}=8.0 \mathrm{~Hz}\right), 7.61-7.64(2 \mathrm{H}, \mathrm{m}), 8.01\left(1 \mathrm{H}, \mathrm{dd},{ }^{3} \mathrm{~J}=8.4 \mathrm{~Hz},{ }^{4} \mathrm{~J}=1.2 \mathrm{~Hz}\right), 9.97\left(1 \mathrm{H}, \mathrm{d},{ }^{4} \mathrm{~J}=1.2 \mathrm{~Hz}\right.$, $\mathrm{CHO}) ; \delta_{\mathrm{C}}\left(100.5 \mathrm{MHz}, \mathrm{CDCl}_{3}\right) 36.4\left(\mathrm{CH}_{2}\right), 71.6\left(\mathrm{OCH}_{2}\right), 72.5\left(\mathrm{OCH}_{2}\right), 126.3(\mathrm{CH}), 127.6(3 \mathrm{C}, \mathrm{CH})$, $127.7(\mathrm{CH}), 128.4(2 \mathrm{C}, \mathrm{CH}), 128.9(2 \mathrm{C}, \mathrm{CH}), 130.1(2 \mathrm{C}, \mathrm{CH}), 130.8(\mathrm{CH}), 133.6(\mathrm{CH}), 133.7\left(\mathrm{C}_{\text {quat }}\right)$, $136.9\left(\mathrm{C}_{\text {quat }}\right), 138.5\left(\mathrm{C}_{\text {quat }}\right), 138.9\left(\mathrm{C}_{\text {quat }}\right), 145.7\left(\mathrm{C}_{\text {quat }}\right), 192.5(\mathrm{CHO})$.

3-(3-Hydroxymethyl-4-methoxyphenyl)benzyl phenylethyl ether (6b) as a colorless oil, prepared according to general procedure $\mathrm{G}$ (see below); $v_{\max }$ (neat, $\mathrm{cm}^{-1}$ ) 3432 (bs, OH), 3016, 2924, 1610, 1482, 1246, 1215 (s), 1086, 1030, 755, 701, 667; $\delta_{\mathrm{H}}\left(400 \mathrm{MHz}, \mathrm{CDCl}_{3}\right) 2.95\left(2 \mathrm{H}, \mathrm{t},{ }^{3} \mathrm{~J}=7.2 \mathrm{~Hz}, \mathrm{CH}_{2}\right)$, $3.73\left(2 \mathrm{H}, \mathrm{t},{ }^{3} \mathrm{~J}=7.2 \mathrm{~Hz}, \mathrm{OCH}_{2}\right), 3.91\left(3 \mathrm{H}, \mathrm{s}, \mathrm{OCH}_{3}\right), 4.58\left(2 \mathrm{H}, \mathrm{s}, \mathrm{OCH}_{2}\right), 4.75\left(2 \mathrm{H}, \mathrm{s}, \mathrm{OCH}_{2}\right), 6.95$ $\left(1 \mathrm{H}, \mathrm{d},{ }^{3} J=8.4 \mathrm{~Hz}\right), 7.23-7.51(10 \mathrm{H}, \mathrm{m}), 7.37\left(1 \mathrm{H}, \mathrm{dd},{ }^{3} \mathrm{~J}=8.2 \mathrm{~Hz},{ }^{3} J=8.2 \mathrm{~Hz}\right) ; \delta_{\mathrm{C}}(100.5 \mathrm{MHz}$, $\left.\mathrm{CDCl}_{3}\right) 36.4\left(\mathrm{CH}_{2}\right), 55.5\left(\mathrm{OCH}_{3}\right), 62.4\left(\mathrm{OCH}_{2}\right), 71.3\left(\mathrm{OCH}_{2}\right), 73.0\left(\mathrm{OCH}_{2}\right), 110.5(\mathrm{CH}), 125.9(\mathrm{CH})$, $126.0(\mathrm{CH}), 126.1(\mathrm{CH}), 126.2(\mathrm{CH}), 127.5(\mathrm{CH}), 127.6(\mathrm{CH}), 128.3(2 \mathrm{C}, \mathrm{CH}), 128.8(\mathrm{CH}), 129.0(2 \mathrm{C}$, $\mathrm{CH}), 129.3\left(\mathrm{C}_{\text {quat }}\right), 133.6\left(\mathrm{C}_{\text {quat }}\right), 138.9\left(\mathrm{C}_{\text {quat }}\right), 139.0\left(\mathrm{C}_{\text {quat }}\right), 140.7\left(\mathrm{C}_{\text {quat }}\right), 157.0\left(\mathrm{C}_{\text {quat }}\right)$

4-(2-Hydroxymethylphenyl)benzyl phenylethyl ether (6a) - General procedure G: To a solution of $\mathbf{5 g}$ $(1.0 \mathrm{~g}, 3.2 \mathrm{mmol})$ in a solvent mixture of $\mathrm{MeOH}(10 \mathrm{~mL})$ and $\mathrm{THF}(10 \mathrm{~mL})$ was given portionwise at $\mathrm{rt}$ $\mathrm{NaBH}_{4}$ (145 mg, $3.8 \mathrm{mmol}$ ). The reaction mixture was stirred for $1 \mathrm{~h}$ at $\mathrm{rt}$. Then, it was given into water (25 mL) and extracted with $\mathrm{CH}_{2} \mathrm{Cl}_{2}(3 \times 15 \mathrm{~mL})$. The organic phase, which showed only one product by TLC, was dried over anhydrous $\mathrm{MgSO}_{4}$ and evaporated in vacuo to obtain $\mathbf{6 a}(975 \mathrm{mg}, 97 \%)$ as a colorless solid; mp. $87-89^{\circ} \mathrm{C}$; $v_{\max }\left(\right.$ neat, $\left.\mathrm{cm}^{-1}\right) 3405$ (bs, OH), 3061, 3026, 2862, 1603, 1482, 1452, 1196, 1096, 1007, 827, 759, 700; $\delta_{\mathrm{H}}\left(400 \mathrm{MHz}, \mathrm{CDCl}_{3}\right) 2.97\left(2 \mathrm{H}, \mathrm{t},{ }^{3} \mathrm{~J}=7.2 \mathrm{~Hz}, \mathrm{CH}_{2}\right), 3.75\left(2 \mathrm{H}, \mathrm{t},{ }^{3} \mathrm{~J}\right.$ $\left.=7.2 \mathrm{~Hz}, \mathrm{OCH}_{2}\right), 4.57\left(2 \mathrm{H}, \mathrm{s}, \mathrm{OCH}_{2}\right), 4.61\left(2 \mathrm{H}, \mathrm{s}, \mathrm{OCH}_{2}\right), 7.22-7.39(12 \mathrm{H}, \mathrm{m}), 7.54\left(1 \mathrm{H}, \mathrm{dd},{ }^{3} J=7.2\right.$ 
$\left.\mathrm{Hz},{ }^{4} J=1.6 \mathrm{~Hz}\right) ; \delta_{\mathrm{C}}\left(100.5 \mathrm{MHz}, \mathrm{CDCl}_{3}\right) 36.4\left(\mathrm{CH}_{2}\right), 63.2\left(\mathrm{OCH}_{2}\right), 71.5\left(\mathrm{OCH}_{2}\right), 72.7\left(\mathrm{OCH}_{2}\right)$, $126.2(\mathrm{CH}), 127.5(\mathrm{CH}), 127.6(\mathrm{CH}), 127.7(2 \mathrm{C}, \mathrm{CH}), 128.3(2 \mathrm{C}, \mathrm{CH}), 128.4(\mathrm{CH}), 128.9(2 \mathrm{C}, \mathrm{CH})$, $129.2(2 \mathrm{C}, \mathrm{CH}), 130.1(\mathrm{CH}), 137.4\left(\mathrm{C}_{\text {quat }}\right), 138.0\left(\mathrm{C}_{\text {quat }}\right), 138.9\left(\mathrm{C}_{\text {quat }}\right), 139.8\left(\mathrm{C}_{\text {quat }}\right), 141.1\left(\mathrm{C}_{\text {quat }}\right)$.

3-(3-[4-Bromobenzyloxymethyl]-4-methoxyphenyl)benzyl phenylethyl ether (7b), obtained through general procedure $\mathrm{C}$ from $\mathbf{6 b}$ and $\mathbf{1 a}$, as a colorless oil; $v_{\max }$ (neat, $\mathrm{cm}^{-1}$ ) 3027, 2856, 1608, 1248, 1086, 1029, 1011, 791, 700; $\delta_{\mathrm{H}}\left(400 \mathrm{MHz}, \mathrm{CDCl}_{3}\right) 2.95\left(2 \mathrm{H}, \mathrm{t},{ }^{3} \mathrm{~J}=7.2 \mathrm{~Hz}, \mathrm{CH}_{2}\right), 3.73\left(2 \mathrm{H}, \mathrm{t},{ }^{3} \mathrm{~J}=7.2 \mathrm{~Hz}\right.$, $\left.\mathrm{OCH}_{2}\right), 3.86\left(3 \mathrm{H}, \mathrm{s}, \mathrm{OCH}_{3}\right), 4.57\left(2 \mathrm{H}, \mathrm{s}, \mathrm{OCH}_{2}\right), 4.58\left(2 \mathrm{H}, \mathrm{s}, \mathrm{OCH}_{2}\right), 4.62\left(2 \mathrm{H}, \mathrm{s}, \mathrm{OCH}_{2}\right), 6.93(1 \mathrm{H}, \mathrm{d}$, $\left.{ }^{3} J=8.4 \mathrm{~Hz}\right), 7.19-7.50(11 \mathrm{H}, \mathrm{m}), 7.37\left(1 \mathrm{H}, \mathrm{dd},{ }^{3} J=7.6 \mathrm{~Hz},{ }^{3} J=7.6 \mathrm{~Hz}\right), 7.46\left(2 \mathrm{H}, \mathrm{d},{ }^{3} J=8.4 \mathrm{~Hz}\right)$, $7.62\left(1 \mathrm{H}, \mathrm{d},{ }^{4} J=2.4 \mathrm{~Hz}\right) ; \delta_{\mathrm{C}}\left(100.5 \mathrm{MHz}, \mathrm{CDCl}_{3}\right) 36.4\left(\mathrm{CH}_{2}\right), 55.5\left(\mathrm{OCH}_{3}\right), 67.2\left(\mathrm{OCH}_{2}\right), 71.3$ $\left(\mathrm{OCH}_{2}\right), 71.7\left(\mathrm{OCH}_{2}\right), 73.0\left(\mathrm{OCH}_{2}\right), 110.5(\mathrm{CH}), 121.3\left(\mathrm{C}_{\text {quat }}\right), 126.0(2 \mathrm{C}, \mathrm{CH}), 126.1(2 \mathrm{C}, \mathrm{CH}), 126.2$ $\left(\mathrm{C}_{\text {quat }}\right), 127.4(\mathrm{CH}), 127.9\left(\mathrm{C}_{\text {quat }}\right), 128.3(2 \mathrm{C}, \mathrm{CH}), 128.8(\mathrm{CH}), 128.9(2 \mathrm{C}, \mathrm{CH}), 129.4(2 \mathrm{C}, \mathrm{CH}), 131.4$ $(2 \mathrm{C}, \mathrm{CH}), 133.4\left(\mathrm{C}_{\text {quat }}\right), 137.6\left(\mathrm{C}_{\text {quat }}\right), 138.8(\mathrm{CH}), 138.9\left(\mathrm{C}_{\text {quat }}\right), 140.9\left(\mathrm{C}_{\text {quat }}\right), 156.8\left(\mathrm{C}_{\text {quat }}\right)$.

3-(3-[4-Phenylbenzyloxymethyl]-4-methoxyphenyl)benzyl phenylethyl ether $(\mathbf{8 b})$ as a colorless oil; $\delta_{\mathrm{H}}$ $\left(400 \mathrm{MHz}, \mathrm{CDCl}_{3}\right) 2.95\left(2 \mathrm{H}, \mathrm{t},{ }^{3} \mathrm{~J}=6.8 \mathrm{~Hz}, \mathrm{CH}_{2}\right), 3.72\left(2 \mathrm{H}, \mathrm{t},{ }^{3} J=6.8 \mathrm{~Hz}, \mathrm{OCH}_{2}\right), 3.88(3 \mathrm{H}, \mathrm{s}$, $\left.\mathrm{OCH}_{3}\right), 4.58\left(2 \mathrm{H}, \mathrm{s}, \mathrm{OCH}_{2}\right), 4.69\left(4 \mathrm{H}, 2 \mathrm{~s}, 2 \mathrm{OCH}_{2}\right), 6.95\left(1 \mathrm{H}, \mathrm{d},{ }^{3} J=8.4 \mathrm{~Hz}\right), 7.18-7.60(19 \mathrm{H}, \mathrm{m})$, $7.68\left(1 \mathrm{H}, \mathrm{d},{ }^{4} J=2.0 \mathrm{~Hz}\right) ; \delta_{\mathrm{C}}\left(100.5 \mathrm{MHz}, \mathrm{CDCl}_{3}\right) 36.4\left(\mathrm{CH}_{2}\right), 55.5\left(\mathrm{OCH}_{3}\right), 67.2\left(\mathrm{OCH}_{2}\right), 71.3$ $\left(\mathrm{OCH}_{2}\right), 72.2\left(\mathrm{OCH}_{2}\right), 73.0\left(\mathrm{OCH}_{2}\right), 110.5(\mathrm{CH}), 125.9(\mathrm{CH}), 126.0(\mathrm{CH}), 126.1(\mathrm{CH}), 126.2(\mathrm{CH})$, $126.9\left(\mathrm{C}_{\text {quat }}\right), 127.0(2 \mathrm{C}, \mathrm{CH}), 127.1(2 \mathrm{C}, \mathrm{CH}), 127.2(\mathrm{CH}), 127.3(\mathrm{CH}), 127.9(\mathrm{CH}), 128.2(2 \mathrm{C}, \mathrm{CH})$, $128.3(2 \mathrm{C}, \mathrm{CH}), 128.7(3 \mathrm{C}, 3 \mathrm{CH}), 128.9(2 \mathrm{C}, \mathrm{CH}), 133.4\left(\mathrm{C}_{\text {quat }}\right), 137.6\left(\mathrm{C}_{\text {quat }}\right), 138.8\left(\mathrm{C}_{\text {quat }}\right), 138.9$ $\left(\mathrm{C}_{\text {quat }}\right), 140.5\left(\mathrm{C}_{\text {quat }}\right), 141.0\left(2 \mathrm{C}, \mathrm{C}_{\text {quat }}\right), 156.8$ ( $\left.\mathrm{C}_{\text {quat }}\right)$.

4-[2-(4-Bromobenzyloxy)methylphenyl]benzyl phenylethyl ether (7a) as a colorless oil; $\delta_{\mathrm{H}}(400 \mathrm{MHz}$, $\left.\mathrm{CDCl}_{3}\right) 2.98\left(2 \mathrm{H}, \mathrm{t},{ }^{3} J=7.2 \mathrm{~Hz}, \mathrm{CH}_{2}\right), 3.76\left(2 \mathrm{H}, \mathrm{t},{ }^{3} \mathrm{~J}=7.2 \mathrm{~Hz}, \mathrm{OCH}_{2}\right), 4.41\left(2 \mathrm{H}, \mathrm{s}, \mathrm{OCH}_{2}\right), 4.43(2 \mathrm{H}$, $\left.\mathrm{s}, \mathrm{OCH}_{2}\right), 4.58\left(2 \mathrm{H}, \mathrm{s}, \mathrm{OCH}_{2}\right), 7.14\left(2 \mathrm{H}, \mathrm{d},{ }^{3} \mathrm{~J}=8.4 \mathrm{~Hz}\right), 7.20-7.56(13 \mathrm{H}, \mathrm{m}), 7.42\left(2 \mathrm{H}, \mathrm{d},{ }^{3} J=8.0\right.$ $\mathrm{Hz}) ; \delta_{\mathrm{C}}\left(100.5 \mathrm{MHz}, \mathrm{CDCl}_{3}\right) 36.4\left(\mathrm{CH}_{2}\right), 70.2\left(\mathrm{OCH}_{2}\right), 71.5\left(\mathrm{OCH}_{2}\right), 71.6\left(\mathrm{OCH}_{2}\right), 72.8\left(\mathrm{OCH}_{2}\right)$, $121.4\left(\mathrm{C}_{\text {quat }}\right), 126.2(\mathrm{CH}), 127.4(2 \mathrm{C}, \mathrm{CH}), 127.5(\mathrm{CH}), 127.8(\mathrm{CH}), 128.4(2 \mathrm{C}, \mathrm{CH}), 128.9(2 \mathrm{C}, \mathrm{CH})$, $129.2(2 \mathrm{C}, \mathrm{CH}), 129.3(2 \mathrm{C}, \mathrm{CH}), 129.4(\mathrm{CH}), 130.0(\mathrm{CH}), 131.4(2 \mathrm{C}, \mathrm{CH}), 135.1\left(\mathrm{C}_{\text {quat }}\right), 137.2\left(\mathrm{C}_{\text {quat }}\right)$, $137.3\left(\mathrm{C}_{\text {quat }}\right), 138.9\left(\mathrm{C}_{\text {quat }}\right), 140.0\left(\mathrm{C}_{\text {quat }}\right), 141.8\left(\mathrm{C}_{\text {quat }}\right)$.

\section{Conclusion}

New benzyl ethers have been synthesized as potential heat transfer fluids (HTFs). Within the synthetic route, a one pot etherification - Suzuki cross coupling protocol has been developed, which in some cases can be run solventless with $\mathrm{Pd} / \mathrm{C}$ as catalyst under ambient atmosphere. This protocol is more resource-efficient than conventional reaction processes of this type.

The ethers prepared have been calculated to have a relatively high specific heat capacity, which in some cases has been validated experimentally. It has been shown by thermal gravimetric analysis that the extended ethers (such as $\mathbf{8 b}$ ) are stable up to $300{ }^{\circ} \mathrm{C}$, even in air, ie., at temperatures that are interesting for the operation of HTFs. 


\section{Acknowledgment}

This work was supported by SURE project fund 31S097.

\section{Conflict of Interest}

The authors see no conflict of interest.

\section{References and Notes}

1. Tumuluri, K.; Alvarado, J.L.; Taherian, H.; Marsh, C. Thermal performance of a novel heat transfer fluid containing multiwalled carbon nanotubes and microencapsulated phase change materials. International Journal of Heat and Mass Transfer. 2011, 54, 5554-5567.

2. Tataroglu, F.S.; Mansoori, Y. Synthetic heat carrier oil compositions based on polyalkylene glycols. Energy Conversion and Management, 2007, 48, 703-708.

3. Duffie, J.A.; Backman, W.A. Solar Engineering of Thermal Processes, 3rd ed.; John Wiley \& Sons, Inc: New Jersey, USA, 2006; pp. 375.

4. Hall, S. Rules of Thumb for Chemical Engineers, 5th ed.; Butterworth, Heinemann (Elsevier imprint), USA, 2012; pp. 204-219.

5. Murphy, L.M.; Keneth, E. Steam Generation in Line-Forced Solar Collectors: A Comparative Assessment of Thermal Performance, Operating Stability, and Cost Issues. SERI/TR-1311, Golden, CO, USA. 1982.

6. Al Jasem, Y.; Thiemann, T. A system for converting thermal energy into electrical energy. Patent application, 2013.

7. Eissen, M.; Metzger, J.O.; Schmidt, E.; Schneidewind, U. 10 years after Rio - concepts of the contribution of chemistry to a sustainable development. Angew. Chem. Int. Ed. Engl. 2002, 41, $414-436$.

8. Rao, H.S.P.; Senthilkumar, S.P. A convenient procedure for the synthesis of allyl and benzyl ethers from alcohols and phenols, Proc. Indian Acad. Sci. 2001, 113, 191 - 196.

9. Thiemann, T.; Watanabe, M.; Tanaka, Y.; Mataka, S. One pot Suzuki coupling - Wittig olefination reactions. J. Chem. Res. 2004, 28, 723 - 727.

10. Watanabe, M.; Mataka, S.; Thiemann, T. One Pot Sonogashira-Coupling / Wittig olefination procedures. J. Chem. Res. 2005, 29, 636 - 639.

11. Yamamoto, K.; Watanabe, M.; Ideta, K.; Mataka, S.; Thiemann, T. Combined Suzuki coupling - Wittig olefination reaction in aqueous medium. Z. Naturforschg. B 2005, 60B, 1299 - 1307. 
12. Thiemann, T.; Watanabe, M.; Tanaka, Y.; Mataka, S. One-Pot Wittig-olefination / Suzukireaction - the Compatibility of conjugated phosphoranes in $\mathrm{Pd}(0)$ catalysed $\mathrm{C}$-C-bond forming reactions. New J. Chem. 2006, 30, 359 - 369.

13. Burmester, C.; Mataka, S.; Thiemann, T. Synthesis of non-symmetric Divinylarenes by a Heck/Wittig reaction combination. Synth. Commun., 2010, 40, 3196 - 3208.

14. Jeffery, T. On the efficiency of tetraalkylammonium salts in Heck reactions, Tetrahedron 1996, $52,10113-10130$.

15. Jeffery, T.; Galland, J.C. Tetraalkylammonium salts in Heck-type reactions using an alkali metal hydrogen carbonate or an alkali metal acetate as the base, Tetrahedron Lett. 1994, 35, 4103 - 4106.

16. Yamamoto, K; Thiemann, T. Suzuki-Miyaura cross-coupling and Heck-Mizoroki reactions catalysed by Pd on carbon nanofibres. J. Chem. Res. 2011, 35, 246 - 250.

17. Yamamoto, K. Pd on carbon nanofibres - Synthesis and Reactivity, MSc thesis, Kyushu University, 2007.

18. Joback, K.G.; Reid, R.C. Estimation of Pure-Component Properties from Group-Contributions. Chem. Eng. Comm. 1987, 57, 233-243.

19. Lydersen, A.L. Estimation of critical properties of organic compounds, College Engineering University Wisconsin, Engineering Experimental Station Report 3, Madison, WI, April, 1955.

20. Ambrose, D. Correlation and estimation of vapor-liquid critical properties. I. Critical temperatures of organic compounds, National Physical Laboratory, Teddington, UK, NPL Report Chem., 92, September 1978.

21. Klincewicz, K.M.; Reid, R.C. Estimation of critical properties with group contribution methods. AIChE J. 1984, 30, 137-142.

22. Lyman, W.J.; Reehl, W.F.; Rosenblatt, D.H. Handbook of Chemical Property Estimation Methods, American Chemical Society, Washington, DC, 1990.

23. Horvath, A.L. Molecular Design, Elsevier, Amsterdam, 1992.

24. Marrero, J.; Gani, R. Group-contribution based estimation of pure component properties. Fluid Phase Equilibria, 2001, 183-208

25. Kolská, Z.; Kukal, J.; Zábranský, M.; Růžička, V. Estimation of the Heat Capacity of Organic Liquids as a Function of Temperature by a Three-Level Group Contribution Method. Ind. Eng. Chem. Res. 2008, 47, 2075-2085. 
(C) 2013 by the authors; licensee MDPI, Basel, Switzerland. This article is an open access article distributed under the terms and conditions of the Creative Commons Attribution license (http://creativecommons.org/licenses/by/3.0/). 